\title{
FULL SCALE PROCESS DESIGN FOR ENERGY RECOVERY FROM APPLE WASTE AT THE EPLEBLOMSTEN JUICE FACTORY
}

\author{
Timothy Greer \\ Yuan Song \\ Wenjun $W u$ \\ Deshai Botheju \\ Rune Bakke \\ Telemark University College, Norway
}

\begin{abstract}
The aim of this project was to design a biogas process to recovery energy from the apple waste for Epleblomsten juice factory. The apple waste was proposed to be treated by extracting a liquid with high organic content from the solid apple waste and treating this leachate. From other studies the apple waste leachate organic content had been found to be in the range from 80 to $180 \mathrm{~kg} \mathrm{COD} / \mathrm{m}^{3}$. These values and information regarding the leachate composition were used to design and simulate various full scale processes. The factory energy requirement was estimated at $400 \mathrm{kWh}$ during full production and reactor was designed and simulated at the various leachate concentrations to produce enough energy to meet the demand of the factory. It was found that a traditional completely stirred mixed reactor (CSTR) required a volume of $\sim 74 \mathrm{~m}^{3}$ to produce enough biogas for the energy demand while a UASB reactor of $18.5 \mathrm{~m}^{3}$ volume was determined capable of producing the same peak biogas demand. The UASB process requires a relatively particle free feed, obtained by extracting a leachate from the solids. It is therefore concluded that a high efficiency biogas process can be obtained by treating leachate instead of the whole waste slurry. It was also theoretically determined that the biogas from the waste leachate can meet the factory energy demand all year around and energy (biogas) production rates could be adjusted by adjusting the feed of leachate to the reactor.
\end{abstract}

\section{KEY WORDS}

Apple waste; Biogas; Design; Energy.

\section{INTRODUCTION}

The Epleblomsten apple processing facility in Norway currently produces apple waste from juice production and this report focus on the use of this apple waste to produce energy as biogas for factory operation. Over the autumn period between mid September and mid December when Epleblomsten is processing the apples, approximately $2,000 \mathrm{~kg} / \mathrm{d}$ of apple waste is produced. Assuming the production is 7 days a week for 3 months then there is about 180 tons of apple waste produced per year [1]. The aim is to design an energy recovery system for Epleblomsten which converts the apple waste into biogas which can then be subsequently used as energy within the plant and maybe distributed to nearby neighbors. The apple waste will be stored in a storage tank and leachate drawn out via a sieve arrangement 
when required therefore the leachate flow can be adjusted allowing control of the biogas production.

An estimate of the COD concentration of between 80 and $180 \mathrm{~kg} / \mathrm{m}^{3}$ was obtained from other experiments [1]. This information was then used to estimate the required flow of apple waste leachate to cover the energy requirements of the plant. The factory at Epleblomsten has a varying energy demand throughout the year so it is best to size the system to match the maximum demand. The process behavior during seasons with lower demand is simulated to observe how such a system can handle large production variations. This was done both for a traditional CSTR reactor design and a high rate UASB. The aim of the study is to estimate process volumes, process behavior and to evaluate the feasibility of such a solution to handle the energy requirements of the fruit juice factory.

\section{DESIGN CRITERIA}

The Epleblomsten fruit juice factory has the following energy requirements through the year: $400 \mathrm{kWh}$ during the main production phase; $200 \mathrm{kWh}$ during the winter; $100 \mathrm{kWh}$ during the spring; $30 \mathrm{kWh}$ during the summer. The energy requirement of the juice factory is about 68 MWh per year, which requires $19,125 \mathrm{~kg}$ of theoretical COD conversion of substrate to methane. 180 tons of apple leachate waste is produced each year [1], which, at a COD concentration of $160 \mathrm{~kg} / \mathrm{m}^{3}$ is $28,800 \mathrm{~kg}$ of COD. This implies a potential energy surplus of $\sim 35 \mathrm{MWh}$ per year (assuming $1 \mathrm{~kg}$ COD converts to $3.55 \mathrm{kWh}$ ). If the apple waste is allowed to age and decay for longer periods, then the feed COD concentration in the leachate could increase leading to a larger energy surplus for each year.

$1 \mathrm{~kW}$ is $1 \mathrm{~kJ} / \mathrm{s}$ therefore $1 \mathrm{kWh}$ is 3,600 seconds multiplied by $1 \mathrm{~kJ}=3,600 \mathrm{~kJ}$ or $3.6 \mathrm{MJ}$. To produce the maximum demand of $400 \mathrm{kWh}$ requires $400 \times 3.6=1440 \mathrm{MJ}$ of energy. Methane has a heat value of $36 \mathrm{MJ}$ per $\mathrm{Nm}^{3}$ [2] which equates to $40 \mathrm{Nm}^{3}$ of methane required for $400 \mathrm{kWh}$. The reactor is operating at $35^{\circ} \mathrm{C}$ therefore need to correct for temperature.

$$
\begin{aligned}
& n=\frac{P V}{R T}=\frac{101325 \times 40}{8.314 \times(273)}=1785 \mathrm{mols} \\
& V=\frac{n R T}{P}=\frac{1785 \times 8.314 \times(273+35)}{101325}=45 \mathrm{~m}^{3}\left(35^{\circ}\right)
\end{aligned}
$$

From literature [2] at $35^{\circ} \mathrm{C} 0.4 \mathrm{~m}^{3}$ of methane is produced per $\mathrm{kg}$ of COD substrate converted. Therefore $400 \mathrm{kWh}$ requires $45 / 0.4=112.5 \mathrm{~kg}$ COD of substrate.

\subsection{CSTR design}

Feed volume required is estimated based on the range of apple waste COD concentrations reported: At $80 \mathrm{~kg} \mathrm{COD} / \mathrm{m}^{3}$ then require $112.5 / 80=1.4 \mathrm{~m}^{3}$ of inlet flow per day while $180 \mathrm{~kg}$ $\mathrm{COD} / \mathrm{m}^{3}$ requires $112.5 / 180=0.6 \mathrm{~m}^{3}$ feed per day.

Various sized CSTR volumes where simulated and an optimal trade off between capital cost of building a large volume or less ability to respond to changes with a smaller volume was reached. 


\subsection{UASB design}

By separating the HRT from the SRT using a UASB reactor where the solids are effectively kept within the reactor then the HRT can be reduced. A key design requirement based on practical experience is to keep the solids loading into the reactor at less than $24 \mathrm{~kg} \mathrm{COD} / \mathrm{m}^{3} \mathrm{~d}$ $\left(\right.$ at $35^{\circ} \mathrm{C}$ ) [2]. Recommended design loading rate is $18 \mathrm{~kg} \mathrm{COD} / \mathrm{m}^{3}$ day [2]. For $400 \mathrm{kWh}$ $112.5 \mathrm{~kg}$ of substrate is required to be converted therefore the volume of the reactor is estimated at $112.5 / 18=6.3 \mathrm{~m}^{3}$. To allow for a large factor of safety [3], and thereby a high degree of conversion of feed to biogas, a liquid volume of $18.5 \mathrm{~m}^{3}$ is chosen. It is noted that the design volume is independent of the feed concentration for such concentrated feeds, because it is directly dependent on the $\mathrm{kg}$ of COD required per day.

\section{METHOD}

The ADM1 model implemented in Aquasim [3] was used to simulate full scale CSTR and UASB reactors. The initial values in the model are given in Table $l$ and are based on ADMl values with slight modifications based on lab experiments [1]. The input state values are given in Table 2 for the values which are deemed to be major contributors to the feed concentration, estimated based on small scale batch experiments [1]. The feed concentrations substrate values add up to $160 \mathrm{~kg} / \mathrm{m}^{3}$ which was deemed a representative value for this apple waste leachate feed.

Table 1. Initial condition for CSTR and UASB reactors.

\begin{tabular}{cccccc}
\hline State & $\begin{array}{c}\text { Initial } \\
\text { concentration } \\
\left(\mathrm{kg} / \mathrm{m}^{3}\right)\end{array}$ & State & $\begin{array}{c}\text { Initial } \\
\text { concentration } \\
\left(\mathrm{kg} / \mathrm{m}^{3}\right)\end{array}$ & State & $\begin{array}{c}\text { Initial } \\
\text { concentration } \\
\left(\mathrm{kg} / \mathrm{m}^{3}\right)\end{array}$ \\
\hline $\mathrm{S} \mathrm{aa}$ & 0.0056 & $\mathrm{~S}$ hion & $6.28 \mathrm{E}-07$ & $\mathrm{X} \mathrm{c}$ & 0.2 \\
\hline $\mathrm{S} \mathrm{ac}$ & 0.0047 & $\mathrm{~S} \mathrm{I}$ & 1.67 & $\mathrm{X} \mathrm{c} 4$ & 0.5 \\
\hline $\mathrm{S}$ an & 0.00457 & $\mathrm{~S}$ in & 0.0324416 & $\mathrm{X} \mathrm{ch}$ & 0.010345 \\
\hline $\mathrm{S}$ bu & 0.014 & $\mathrm{~S} \mathrm{pro}$ & 0.01796 & $\mathrm{X} \mathrm{fa}$ & 0.390943 \\
\hline $\mathrm{S}$ cat & 0.0398 & $\mathrm{~S} \mathrm{su}$ & 0.1 & $\mathrm{X} \mathrm{h} 2$ & 0.223733 \\
\hline $\mathrm{S} \mathrm{ch} 4$ & 0 & $\mathrm{~S} \mathrm{va}$ & 0.001172 & $\mathrm{X}$ & 1.994 \\
\hline $\mathrm{S} \mathrm{co} 2$ & 0 & $\mathrm{X} \mathrm{aa}$ & 0.2 & $\mathrm{X} \mathrm{li}$ & 0.002932 \\
\hline $\mathrm{S} \mathrm{fa}$ & 0.00106 & $\mathrm{X} \mathrm{ac}$ & 1.0 & $\mathrm{X} \mathrm{pr}$ & 0.010345 \\
\hline $\mathrm{S} \mathrm{h} 2$ & 0 & $\mathrm{X} \mathrm{pro}$ & 0.7 & & \\
\hline $\mathrm{S} \mathrm{h}$ ho3 & 0.06718 & $\mathrm{X} \mathrm{su}$ & 1 & & \\
\hline
\end{tabular}

\subsection{CSTR simulation}

The flow is varied throughout the year to meet the required energy requirement. $Q_{\text {in }}$ in Table 3 is the flow required for $400 \mathrm{kWh}$ and the flow is pro-rated down for the lower energy requirements of 200,100 and $30 \mathrm{kWh}$ respectively. Step changes in flow rate are used within the simulation and the process responds to each flow change. 
Table 2. Simulation input values for apple leachate feed from [1].

\begin{tabular}{|c|c|c|c|}
\hline Substrate & $\begin{array}{c}100 \% \text { apple } \\
\text { leachate } \\
\text { concentration }(\mathrm{g} / \mathrm{L})\end{array}$ & Substrate & $\begin{array}{l}100 \% \text { apple leachate } \\
\text { concentration }(\mathrm{g} / \mathrm{L})\end{array}$ \\
\hline amino acid (S_aa) & 7.4 & $\begin{array}{l}\text { elemental hydrogen } \\
\left(\mathrm{S} \_\mathrm{h}_{2}\right)\end{array}$ & 0 \\
\hline total acetate (S_ac) & 2.4 & total propionate(S_pro) & 8.9 \\
\hline total butyrate (S_bu) & 7.0 & Monosaccharides(S_su) & 131.5 \\
\hline $\begin{array}{l}\text { long chain fatty } \\
\text { acids }\left(S_{-} \text {fa) }\right.\end{array}$ & 1.4 & total valerate(S_va) & 0.6 \\
\hline $\begin{array}{l}\text { soluble inert } \\
\text { COD(S_I) }\end{array}$ & 0 & $\begin{array}{l}\text { carbon content of } \\
\text { methane }\left(\mathrm{S}_{-} \mathrm{ch}_{4}\right)\end{array}$ & 0 \\
\hline \multicolumn{4}{|c|}{$\begin{array}{l}\text { Total substrate COD }(\text { S_coD })=\text { S_aa }+ \text { S_ac+ S_bu+ S_fa+ S_I+ S_h }+ \text { S_pro+ S_su+ S_va+ } \\
\text { S_ch }{ }_{4}=159 \mathrm{~g} / \mathrm{L}\end{array}$} \\
\hline
\end{tabular}

\subsection{UASB simulation}

The process simulated has a reactor volume of $18.5 \mathrm{~m}^{3}$ (as explained above) and a SRT of 30 days greater than the HRT. The inflow concentrations are the same as for the CSTR (Table 2). To avoid process instability is was found necessary to gradually change the input flow rate between the various levels over 30 days, to allow the reactor to adjust to different feed rates and obtain stable $\mathrm{pH}$. For the simulations the flows and concentrations were varied as shown in Table 3.

Table 3. Inflow values used for the UASB simulations with a feed concentration of $160 \mathrm{~kg} / \mathrm{m}^{3}$.

\begin{tabular}{lcc}
\hline Time $(\mathrm{d})$ & Feed flow $\left(\mathrm{m}^{3} / \mathrm{d}\right)$ Qin & Increasing or constant \\
\hline 0 & 0 & Increasing to 90 day value \\
\hline 90 & 0.35 & Constant \\
\hline 180 & 0.18 & Constant \\
\hline 270 & 0.05 & Constant \\
\hline 330 & 0.05 & Increasing to 360 day value \\
\hline 360 & 0.7 & Constant \\
\hline 450 & 0.35 & Constant \\
\hline 540 & 0.18 & Constant \\
\hline 630 & 0.05 & Constant \\
\hline 720 & 0.05 & Increasing to 720 day value \\
\hline
\end{tabular}

\section{RESULTS AND DISCUSSION}

\subsection{Simulation of CSTR $74 \mathrm{~m}^{3}$}

A CSTR reactor size of $74 \mathrm{~m}^{3}$ was chosen as an optimal size based on various simulations of the process with different sized reactor volumes. A small reactor volume possibly required 
buffering capacity in the form of alkalinity addition while a larger volume had a larger capital cost. $74 \mathrm{~m}^{3}$ equates to a HRT of 105 days for the $160 \mathrm{~kg} \mathrm{COD} / \mathrm{m}^{3}$ waste stream.

The simulated biogas production, presented as the corresponding energy value, is shown in Figure $l$ (the energy is $8.85 \mathrm{kWh} / \mathrm{m}^{3}$ methane produced). The feed flow rate was varied each 90 days from 0.7 to 0.35 then 0.18 and finally $0.05 \mathrm{~m}^{3} / \mathrm{d}$. During start up, the flow is changed from no flow to a maximum of $0.7 \mathrm{~m}^{3} / \mathrm{d}$; this is increased over 20 days to allow the biomass to adapt. Also at the start of the next year when the flow is increased from 0.05 to $0.7 \mathrm{~m}^{3} / \mathrm{d}$ this is done over 20 days to allow for a smooth transition. At the other step changes in flow the system reacts well (Figure l).

The simulated reactor $\mathrm{pH}$, for the same case as presented in Figure 1, is shown in Figure 2. It can be seen that the transitions from no feed and very low feed to maximum feed are the critical phases with the lowest $\mathrm{pH}$ levels. The process startup phase is evidently the most critical point as the $\mathrm{pH}$ drops below 6.5, where methanogenesis is inhibited. This suggests that startup requires more than the 20 days allowed in the simulations to make sure process failure does not occur. The $\mathrm{pH}$ is quite stable at the other flow rate transitions and remains within the $\mathrm{pH}$ range for safe operation.

The simulated biogas energy output (Figure l) shows good correlation with the simple theoretical calculations for the amount of methane estimated by pure conversion of substrate (see "Design Criteria"). It is, however, noted that the simulated values are a bit lower, as the simulations also account for the fact that some of the energy of the inlet feed is used for cell growth and not just pure methane production. It is also noted that the nitrogen concentration of the feed was modified to minimize the amount of inhibition caused by the lack of nitrogen. An S_IN value of $0.01 \mathrm{~kg} / \mathrm{m}^{3}$ for the feed seemed to produce good results. The system is sensitive to inadequate $S_{-}$IN and if the value is set below $0.005 \mathrm{~kg} / \mathrm{m}^{3}$ then the system becomes unstable. The ammonia is acting as a buffer which is helping to keep the $\mathrm{pH}$ from dropping. A larger volume allows this value to be lower but that is at extra construction cost.

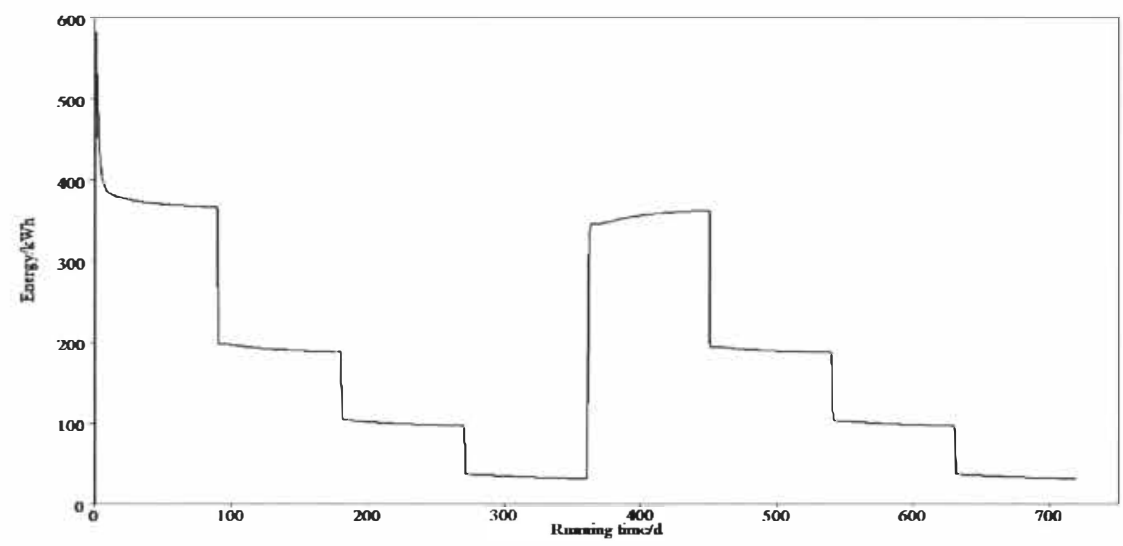

Figure 1. Simulated energy production through two years of operation. 


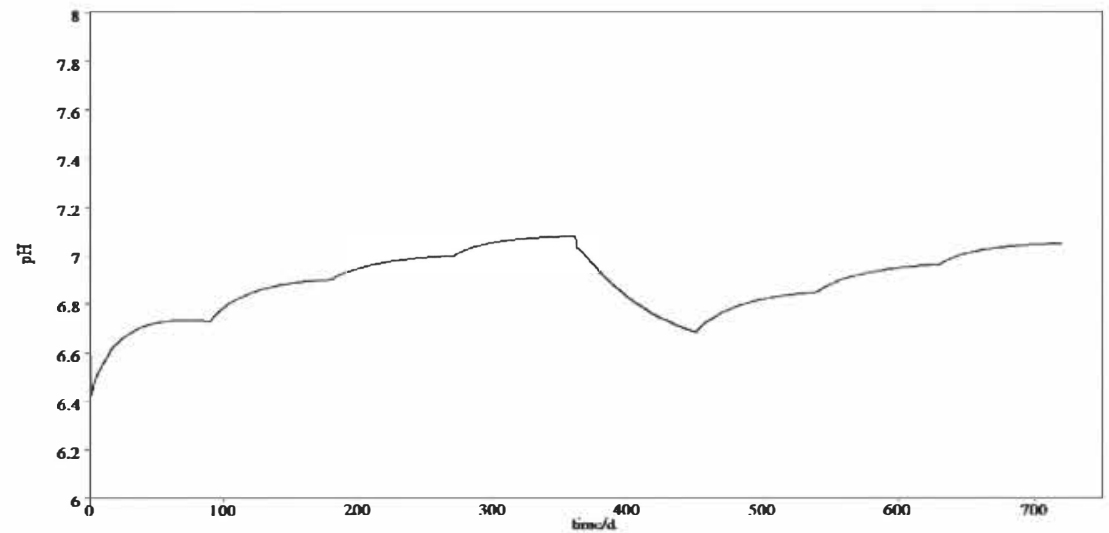

Figure 2. Simulated reactor $p H$ in the tw'o year simulation of Figure 1.

\subsection{Simulation of UASB $18.5 \mathrm{~m}^{3}$}

The simulated UASB biogas production, presented as the corresponding energy value, is shown in Figure 3 (the energy is $8.85 \mathrm{kWh} / \mathrm{m}^{3}$ methane produced). The simulation shows stable production at the levels required. The slow feed load transitions described in Methods were, however, required. The process failed when abrupt feed transitions were simulated.

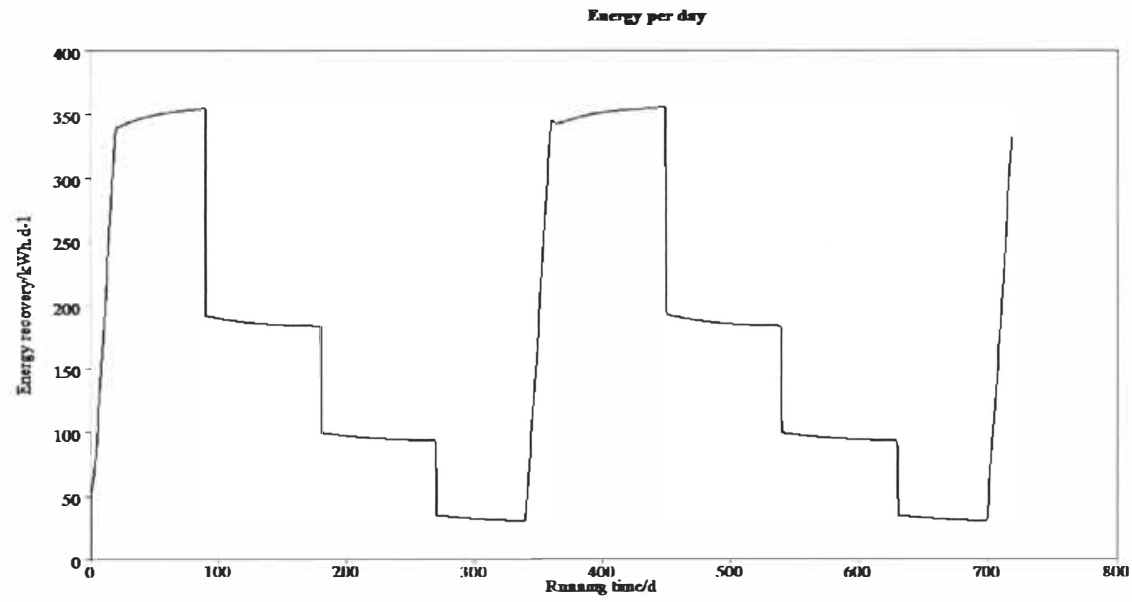

Figure 3. Energy produced from $U A S B$ at $160 \mathrm{~kg} / \mathrm{m}^{3}$ and $0.7 \mathrm{~m}^{3} /$ day. 
It was also observed that this high rate process requires more buffer capacity that the CSTR, supplied as inorganic nitrogen, S_IN, in these simulations. The UASB reactor is sensitive to the S_IN loading, requiring a minimum of $0.05 \mathrm{~kg} / \mathrm{m}^{3}$. An S_IN value of $0.07 \mathrm{~kg} / \mathrm{m}^{3}$ for the feed produces good results (Stable $\mathrm{pH}$ ). This suggests that ammonia or some buffer needs to be added to make a high rate process stable on this feed. A considerably larger volume is required before the low ammonia is not a factor and the UASB reactor approaches the size of the CSTR reactor, defeating the purpose of a high rate process design. A UASB reactor is, however, appropriate given a high enough value of S_IN and allowing a 30-day transition period when increasing the feed flow rate.

\section{CONCLUSIONS}

Simulations of a $74 \mathrm{~m}^{3}$ CSTR biogas reactor over a period of two years with varying feed flows showed that the reactor responded well to step changes in feed and was capable of producing the energy required by the factory. Process instabilities were observed at the start of the juice production season where the energy requirement was increased from 30 to 400 $\mathrm{kWh}$, but this can be reduced by ramping up over a 20 -day period. The ammonia concentration was noted to be a major influence and required a minimum value of 0.005 $\mathrm{kg} / \mathrm{m}^{3}$, otherwise the system became unstable, observed as $\mathrm{pH}$ drops.

The design of the UASB biogas reactor is directly depended on the loading of COD into the reactor volume each day and is therefore independent of the feed concentration (in the feed concentration range relevant for apple waste). Using industry standard design figures of $18 \mathrm{~kg} \mathrm{COD} / \mathrm{m}^{3}$ reactor volume per day, a minimum reactor volume of $6.2 \mathrm{~m}^{3}$ is required for $400 \mathrm{kWh}$ of biogas energy production per day. A factor of safety of 3 is added on to the volume to give a design volume of $18.5 \mathrm{~m}^{3}$. This implies that a HRT of 26 days is required for the UASB to treat the concentrated apple waste leachate $\left(160 \mathrm{kgCOD} / \mathrm{m}^{3}\right)$, which is greater then the 1 day usually associated with UASB reactor designs. Simulating the $18.5 \mathrm{~m}^{3}$ UASB reactor over a two year period with varying feed flows worked well. The reactor responded better to step changes down in feed compared to step changes up. A minimum ramp up period of 30 days is required at the start of each season when there is a large change in the energy demand. The ammonia concentration is also noted to be more significant for the UASB reactor $\mathrm{pH}$ stability than for the CSTR reactor, requiring a minimum of $0.05 \mathrm{~kg} / \mathrm{m}^{3}$ which is 10 times larger than for the CSTR. The actual ammonia concentration of the apple waste is unknown and this could cause problems with the stability of the plant.

\section{ACKNOWLEDGEMENT}

The authors wish to acknowledge the support of the Norwegian Science Foundation.

\section{REFERENCES}

[1] Song, Y., Greer, T., Li, Y., Wu, W., Botheju, D., Bakke, R., 2007. Biogas Potential from Apple Waste, Telemark University College, Porsgrunn.

[2] Tchobanoglous, G., Burton, F., Stensel, D., 2003. Wastewater Engineering: Treatment and Reuse, Metcalf and Eddy. $4^{\text {th }}$ edition, McGraw Hill, Boston, p 993, p985, p1009.

[3] Batstone, D.J., Keller, J., Angelidaki, I., Kalyuzhnyi, S.V., Pavlostathis, S.G., Rozzi, A., Sanders, W.T.M., Siegrist, H,. Vavilin, V.A., 2002. Anaerobic Digestion Model No.1 (ADMI), IWA Task Group for Mathematical Modelling of Anaerobic Digestion Processes. IWA publishing, London. 